\title{
Analysing the Covid-19 Cases in Kerala: a Visual Exploratory Data Analysis Approach
}

\author{
Jayesh $S^{1}$ (D) Shilpa Sreedharan ${ }^{2}$
}

Accepted: 10 August 2020 / Published online: 14 August 2020

(C) Springer Nature Switzerland AG 2020

\begin{abstract}
To analyse the Covid-19 cases and effective measures taken by the Kerala government in India to fight against the pandemic. To conduct an exploratory analysis of the model put forward by Kerala. Data were collected from various sources. Three phases were identified for analysis: first phase starting from January 30 to March 9, 2020; second phase starting from March 10 to May 8 and the last phase from May 9 to May 31,2020. Data analysis was carried out in MATLAB software. The steps taken by the Kerala government ensured the virus to be contained in the affected persons itself. Community spread was reduced by the implementation of contact tracing and home quarantine. Welfare measures taken during the lockdown helped the people to adjust to the changes. The abstinence of community spread still stands strong. Apart from tackling the Covid-19 virus, Kerala with a series of welfare measures made the life of Kerala citizens comfortable. The model raised by Kerala for fighting against Covid-19 can be considered as a benchmark for how the public health department can be utilised properly.
\end{abstract}

Keywords Covid- $19 \cdot$ Coronavirus $\cdot$ Kerala $\cdot$ Data $\cdot$ Analysis $\cdot$ Exploratory analysis $\cdot$ Virus

\section{Introduction}

The new panic in the town, the novel coronavirus disease, abstracted as Covid-19, was first reported as an unexpected outbreak in Wuhan, the capital city of Hubei Province in the People's Republic of China. Within a few weeks, the disease emerged contagiously and spread to different parts of the world. The stupendous containment measures taken by the Chinese government to arrest the spread of the virus got washed down the drain. Being victims of panic and lack of sustainability issues, countries around the globe went to lockdown.

This article is part of the Topical Collection on COVID-19

Jayesh S

jayesh.jhe@gmail.com

Shilpa Sreedharan

drshilpasreedharan@gmail.com

1 Department of Mechanical Engineering, School of Engineering, Cochin University of Science and Technology, Kochi, Kerala 682022, India

2 Wellness Solutions, Kochi, Kerala 682304, India
A rising of infectious disease alarms as rapidly spreading, endangering the health of a large community, the weak being most vulnerable. Immediate action at the root level is required to tackle the virus [1-3].

The first case of Covid-19 in India was reported on January 30, 2020, in Kerala, a southern state in India. The Kerala government under advice from the central boosted up its health and hygiene department and bought in vivid containment, isolation, tracking and other measures to speedily arrest the community spread. Amidst other concern issues, the government with strict measures could resist the immediate spread of the disease, thereby flattening the curve while almost in all other states, the number of patients spiked. Kerala captured the attention of Worldwide Medias and was appreciated for the efficient management of Covid-19 [4-11]. The infrastructure of the public health department in Kerala comprises of primary health centres, community health centres, taluk-level hospitals, district hospitals, general hospitals and medical colleges run by the government. Apart from this, a lot of private hospitals are present. With a set up like this, Kerala successfully fought Nipah virus last year [12]. In this paper, an exploratory data analysis of the Covid-19 cases in Kerala is analysed for a period starting from January 30, 2020, to May 31, 2020. 


\section{Data and Methods}

Covid-19 data from January 30, 2020, to May 31, 2020, is used for this study. In this analysis, the cases in Kerala are divided into three phases: first phase (January 30, 2020 March 9, 2020), second phase (March 10, 2020-May 8) and third phase (May 9-May 31). The division is based on the following facts: The first case was reported in Kerala (also in whole India) on January 30, 2020, from students who returned from China. The state was able to contain the disease within those carriers. No new cases were reported until March 9, 2020. The phase two of the study begins with the cases reported from Italian returnees in Pathanamthitta District of Kerala. This phase was very crucial for the state. Then, in the third phase, when the interstate and intercountry travel was allowed, Keralites in Gulf countries and other foreign countries started reaching Kerala. There was a rise in the number of cases which was predicted beforehand. Until May 31, no traces of community spread were identified. From June 1 onwards, the countrywide lockdown was removed and confined only to containment zones.

\section{Data Collection and Software Used}

Data for this analysis were collected from various sources. The Kerala medical department bulletin publishes the daily details of the condition of the Covid-19 situation. Apart from that, the author uses data from the World Health Organisation (WHO), 'Our World in Data' and John Hopkins Corona Resource Centre [13-16]. Tweets and Facebook corona updates of the Chief Minister and Health Minister of Kerala were also used for the study. Unlike other regions, complete daily data (including minute data) of the state were shared to the public in the Chief Minister's press meet. Media reports around the world were also a source of data. All these sources were used to collect data. MATLAB 2020a is used for exploratory data analysis. The raw data was cleaned using the software. The platform used for the analysis is Windows 7 (64 bit). All the data collected and the code generated in MATLAB are made available in GitHub (https://github.com/ callmejhe1/Covid-19-Data-Analysis).

\section{Measures Taken by the State}

The Government of Kerala implemented a series of measures to fight against the pandemic. In order to track, identify and test all travellers with a potential travel history to Wuhan, a health advisory was constituted beginning January 15, 2020. India's first-ever Covid-19-positive case was reported in Kerala dating January 30, 2020 [17]. Passengers and their immediate contacts were to be under isolation for 28 days. A similar advisory was ventured for student returnees as well [18]. With no further confirmed positive cases being reported immediately, on February 12, the state withdrew the health emergency [19].

When the second wave of infections began spreading in early March, the government took several multi-pronged measures to address the threat. Revised guidelines for the effective clinical management of Covid-19 patients, covering testing, quarantine, hospital admission and discharge, were issued [20-26]. On March 17, Covid-19 was pronounced and declared a notified disaster, thus becoming eligible for funds from the State Disaster Response Fund (SDRF). SDRF remains the primary fund available with state governments for responses to notified disasters [27-29]. Local selfgovernments (panchayaths, municipalities and corporations) can be considered as the major team players in fighting the Covid-19 pandemic [29]. Running awareness programs, such as, 'Break the Chain' initiative; conducting sanitation and cleanliness drives; regular outreach to home isolated/ quarantined persons; activating committee system to manage responsibilities; ensuring the availability of essential commodities; categorising and ensuring available response mechanisms, such as, material resources, volunteers and medical resources and ensuring special attention to vulnerable populations, such as senior citizens, and persons with comorbidities or undergoing special treatments. A round-the-clock war room, comprising members of different departments, was set up to monitor and supervise all Covid-19 containment activities [30, 31]. With the legislature not in session, the Kerala Epidemic Diseases Ordinance, 2020, was promulgated by the Governor of Kerala on March 26 [32]. The Ordinance empowers the state government to undertake any necessary measures and specify regulations to counter the threat of an epidemic disease. It also specifies a penalty for those who violate orders made under this Ordinance.

On March 23, Kerala announced a statewide lockdown until March 31 [33]. A day later, the central government announced a nationwide 21-day lockdown until April 15 [34]. On April 15, the central government extended the lockdown until May 3, which further extended until May 31 [35]. Severe restrictions were imposed under the state's order. 'Home quarantine' and 'contact tracing' were other strategic steps applied successfully across the state. During this period, the strict quarantine was overlooked by local health authorities and police department. This was a major step in the fight against the pandemic to pause its spread. People who were not able to afford home quarantine were arranged for an institutional quarantine. If people under quarantine develop any symptoms, they will be admitted to the hospital in a specially arranged hospital vehicle, thus avoiding any minor chances of virus spread.

A handful of welfare measures were also adopted by the Kerala government. Under SDRF norms, funds were released to the health department for relief and response activities related to Covid-19 [36]. 


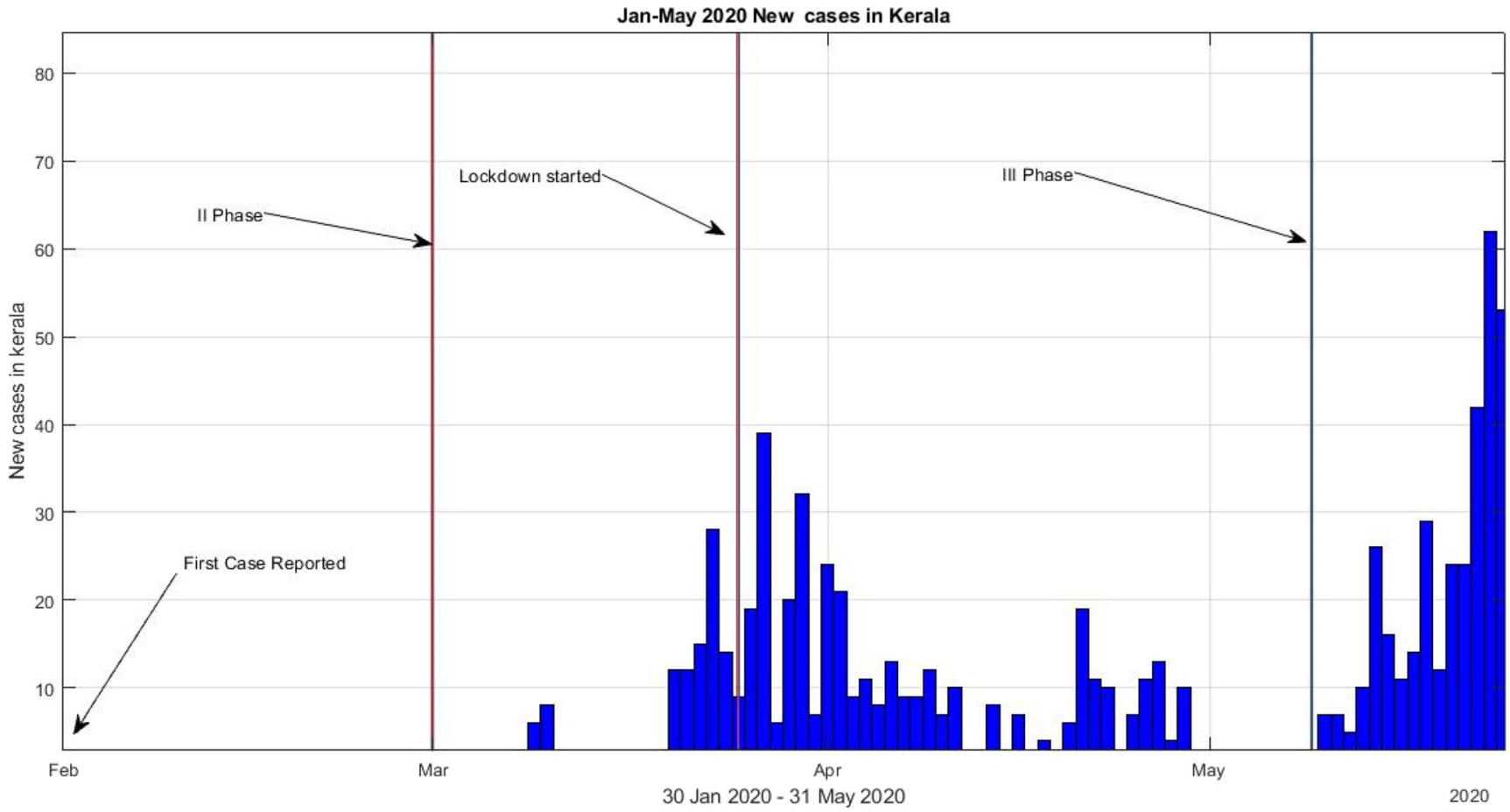

Fig. 1 New cases in Kerala from 30 January-31 May 2020

A 2000 crore worth Chief Minister's Helping Hand Loan Scheme was announced for people facing lockdown-related unemployment and hardships [37]. Through PDS (public distribution system), the government supplied $15 \mathrm{~kg}$ of rice and grocery kit to all ration card holder's family. The assistance of Rs 1000 was given to all eligible families in Kerala who were not getting any benefits from any other welfare schemes.

\section{Medical Department in Kerala}

There are reportedly 14 medical colleges, 18 general hospitals, 18 district hospitals, 46 taluk headquarters hospitals, 40 taluk hospitals, $11424 \times 7$ public health centres (PHC), 568 public health centres and 170 PHCs for family health centres (FHC) run by the Government of Kerala. Two thousand sixty-two

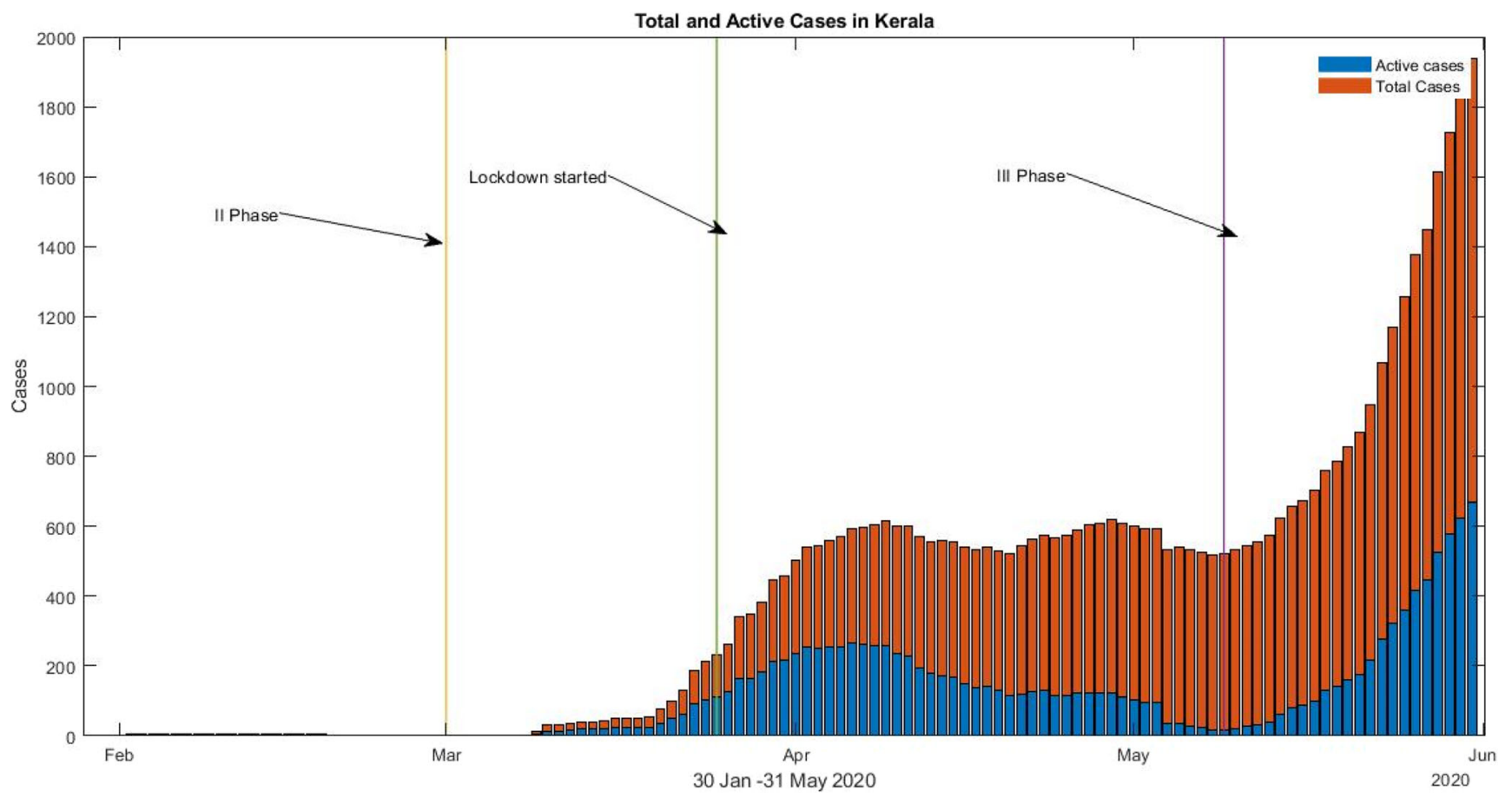

Fig. 2 Total and active cases in Kerala 


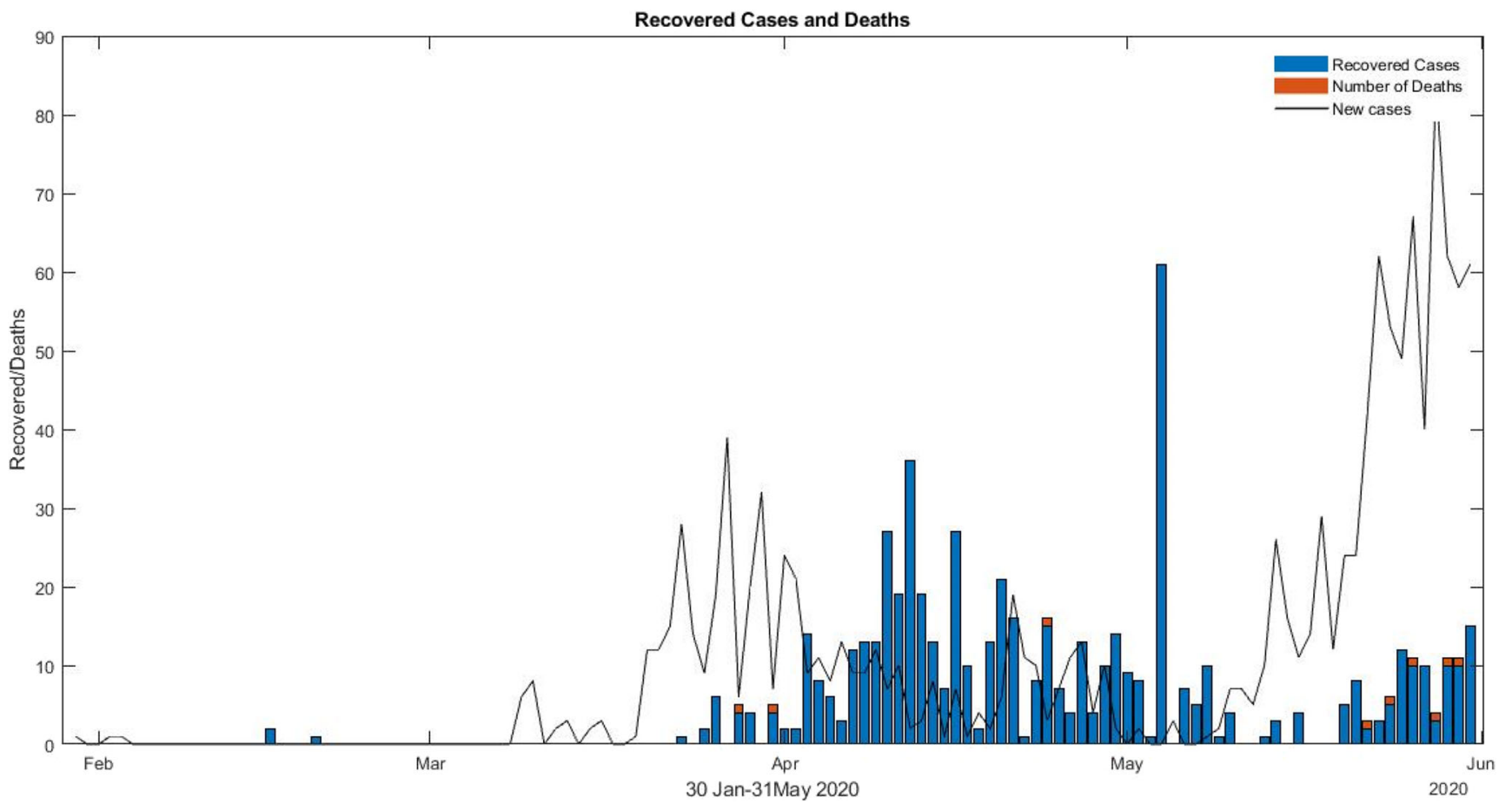

Fig. 3 Stacked plot of recovered cases, deaths and new cases in Kerala

private hospitals are also active in the state. The 'Kerala model' healthcare delivery system has set up the best example for other states to emulate upon. Seven of its primary health centres (PHCs) awarded the National Quality Assurance Standards (NQAS) certification from the National Health Mission, an arm of the Ministry of Health and Family
Welfare recently. Among the seven PHCs, the family health centre at Kayyur in Kerala's Kasaragod district emerged top performer and tagged the best PHC in the country. There are about 38,004 and 61,223 beds, 1900 and 3061 ICU beds and 950 and 1531 ventilators in government and private hospitals respectively.

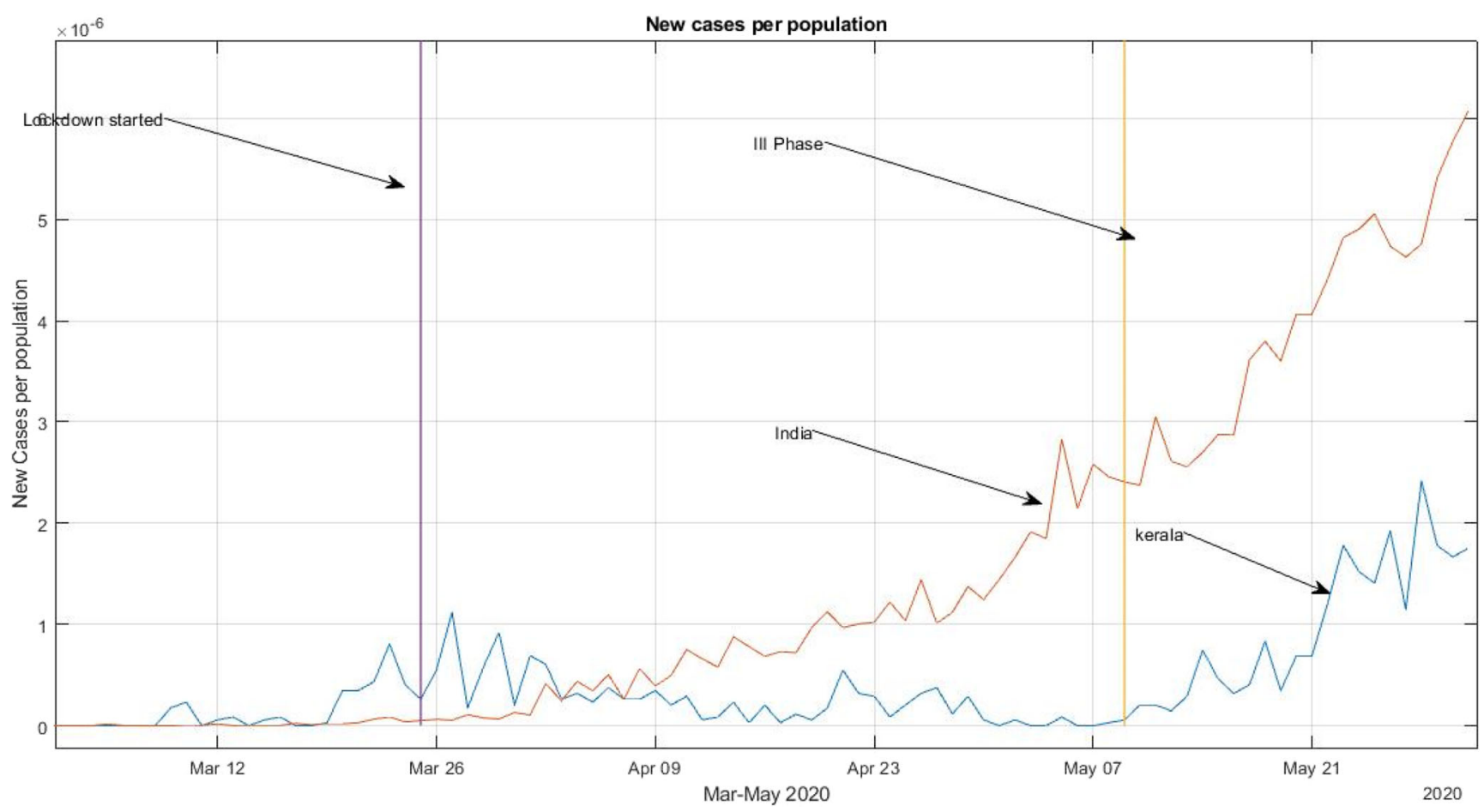

Fig. 4 New cases per population for India and Kerala 


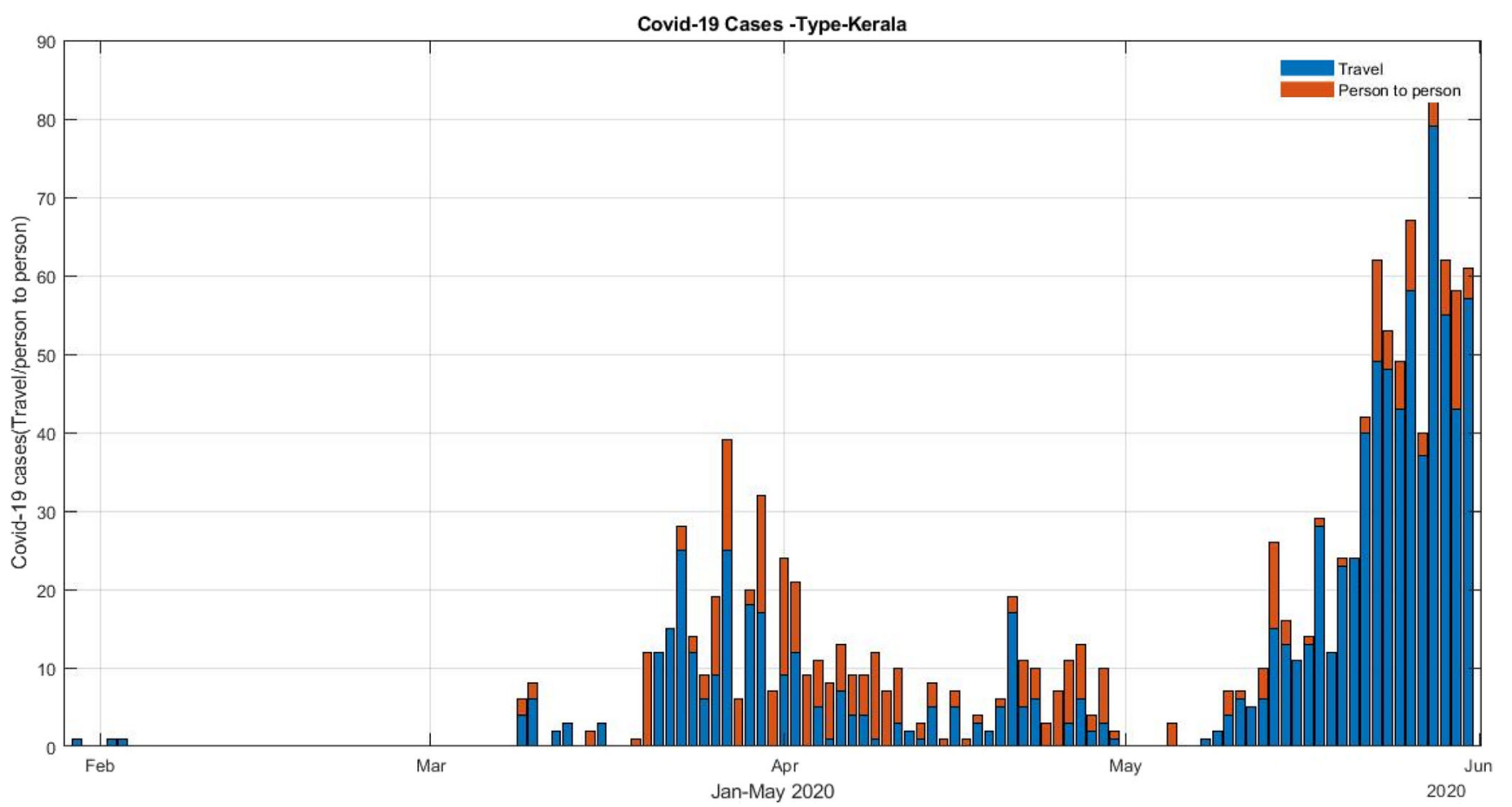

Fig. 5 Type of Covid-19 transmission (travel/person to person)

\section{Results and Discussion}

\section{Kerala Covid-19 Cases}

The initial Covid-19 case was reported on January 30, 2020. In the first phase, a total of three cases were reported. They were properly quarantined in the hospital, observed and treated. The first corona centre was opened in government medical college, Kochi. No other persons were affected by them. By February 20, the three patients recovered and were discharged. No person to person spreading happened in the first phase.

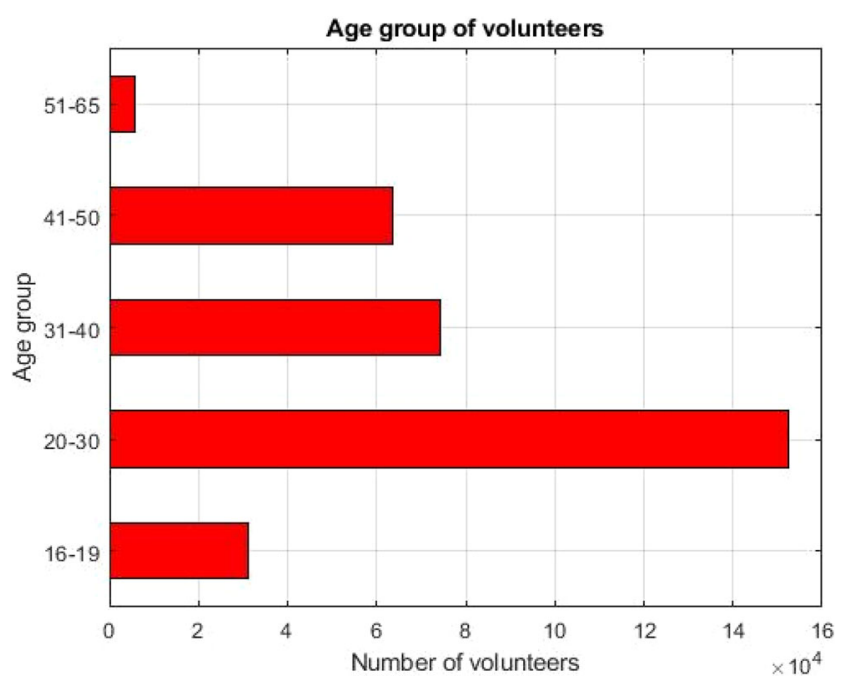

Fig. 6 Age group of volunteers
The 'state calamity' status announced earlier was hence withdrawn. Until March 9, no active cases were present or reported. The second phase of the Covid-19 in Kerala started on this day. Six new cases were reported. It included returnees from Italy who allegedly escaped from the airport testing facility. Meanwhile, there was an increase in the number of cases in Kerala as well as in the other states. Kerala had the most cases in numbers. A number of active cases crossed a hundred by March 24. Kerala then resorted to complete lockdown. The next day, the Government of India also pronounced countrywide lockdown until April 15 which later extended multiple times until May 31. The people who were identified as Covid19 positive were taken to hospital and contact tracing was made. The route map of the patient with their travel date, time and location was published by the district administration and the police department. Availing information from the contact tracing, contact persons were categorised into primary contact and secondary contact. These persons were under strict observation at home or at a government institution. If they develop any positive symptoms, they will be shifted to the corona centre and testing will be done. The testing and hospital expenses were accounted and managed by the government. The treatments were carried out by government hospitals. The private hospitals were also made ready to cope with any emergency spike in cases. The home quarantining measure and contact tracing were very effective in the state that the number of cases began reducing. There were 268 active cases on April 11. After that, the number of cases began reducing. The recovery rate too took its toll on the increase. On May 4, 61 
Fig. 7 Work carried out by the volunteers

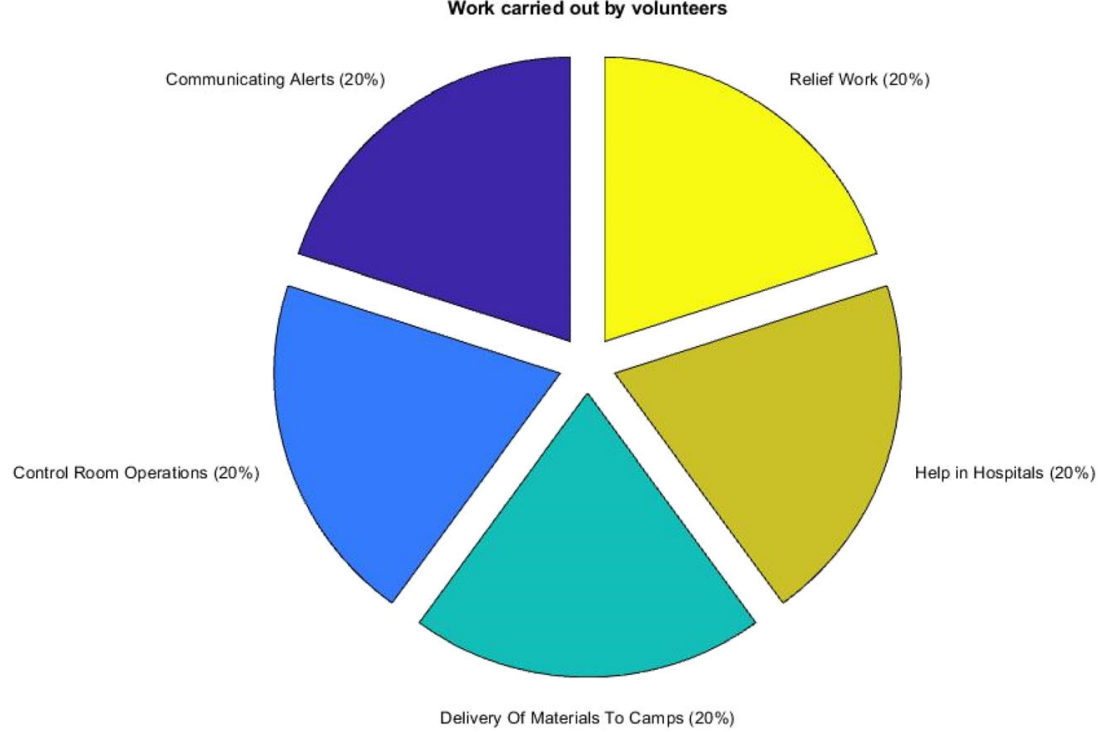

reported during the third phase. The death rate was very less in Kerala. These persons also had a history of other diseases. A comparison of cases in Kerala and the whole India is shown in Figs. 4 and 5.

Parallel coordinate plots are used to compare many variables together. Parallel plots of India cases, Kerala cases and Indian and Kerala cases combined are shown in Figs. 15, 16 and 17 . The relation between cases, deaths and number of tests can be observed from the plot. The death rate of Kerala is much lower than in India. The recovery rate of Kerala is also appreciable. It can also be seen that lockdown was effective in Kerala.

\section{Volunteer}

Another notable step taken by the government was to create a pool of volunteers for Covid-19 resistance. Interested people were informed to register through the government portal. There were restrictions imposed with regard to age, health,
Fig. 8 Activity distribution among the volunteers

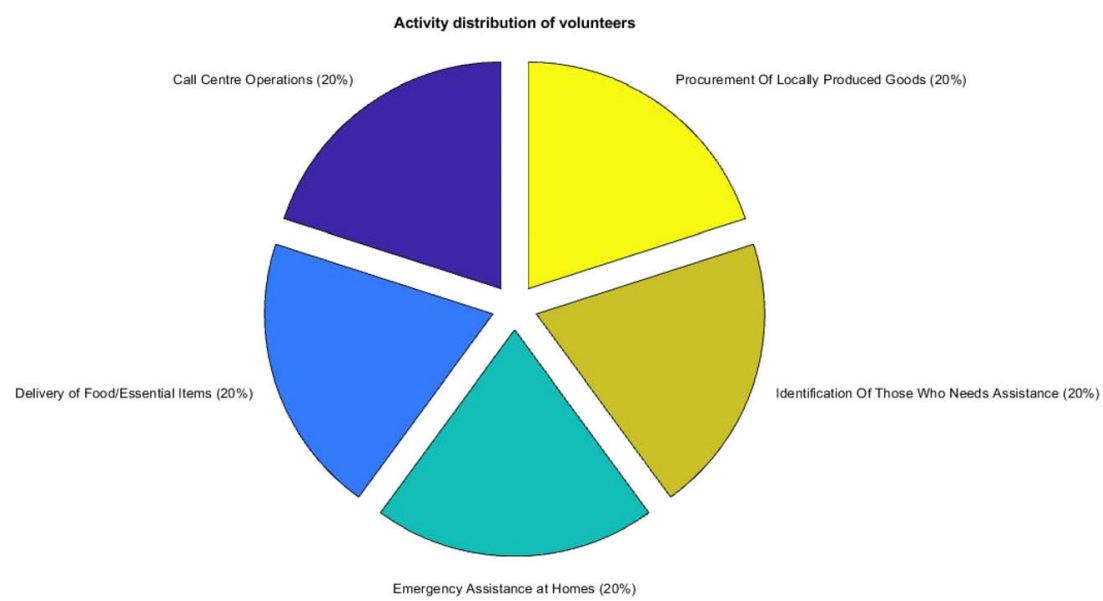




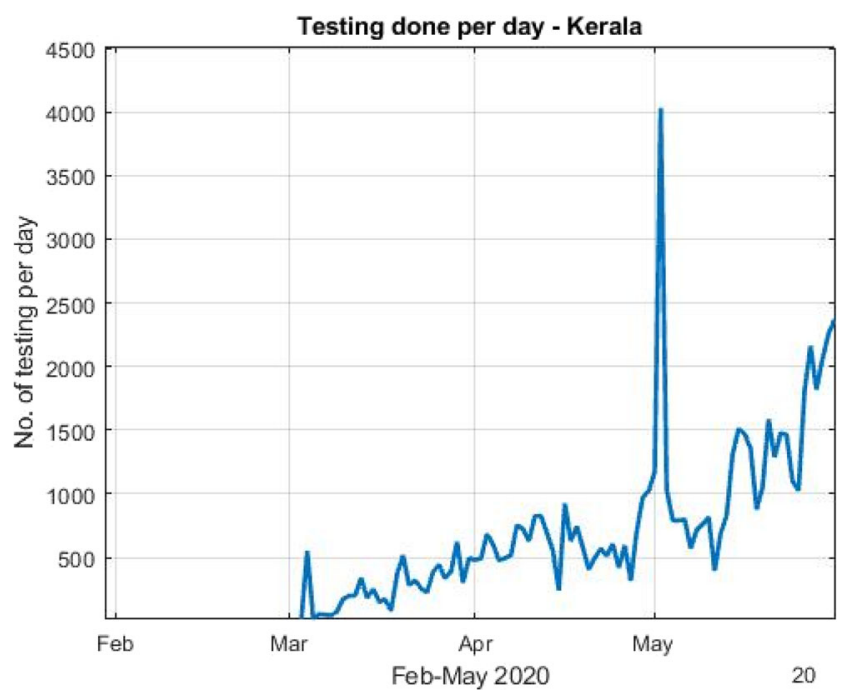

Fig. 9 Testing done per day in Kerala

etc. for registering. A huge response came from the public. A total of 491,508 people registered. The age-wise categorisation is shown in Fig. 6. A total of 116,283 were allocated for the identification of those who need assistance. For delivering food and essential items to the doorstep, 118,917 were allotted. A total of 91,308 were allocated for the procurement of locally produced goods. Emergency assistance at home was given as a task to 91,308 persons. For 74,775 people, call centre duties were assigned. There were increases in the number of volunteers as the registration process was also done in parallel. Pie charts (Figs. 7 and 8) show the percentage-wise split up.

\section{Testing}

There were 14 government labs commissioned for testing the virus in the samples across the state. Six private labs were authorised permission by ICMR. The phase 1 samples were tested in the laboratory in Pune. Later, the state government labs were set up for Covid-19 detection. Initially, the number of tests carried out was considerably less due to various reasons. Gradually, the number of labs and number of tests increased. A total of 67,371 samples were taken for testing as of May 31. A total of 64,093 samples showed negative results. A total of 1269 samples were confirmed positive. Statuses of 2009 samples are awaiting results. The testing details are shown in Fig. 9. Apart from these, 22,855 samples were collected from priority-based groups like health care workers, persons with relatively high social exposure and workers as part of sentinel surveillance of which 6 samples tested positive, 21,230 samples tested negative and awaiting results of 1619.

\section{Quarantine and Hospital Admission Report}

Quarantine and social distancing accounted for efficacious in the state. The home quarantine details during the second phase are shown in Fig. 10. During the second phase, it reached a maximum of 1,70,621 persons under home quarantine as of April 4. After that, there was a significant reduction in the numbers and reached low as 16,383. Post the removal of the ban on the interstate and international travel, a number of

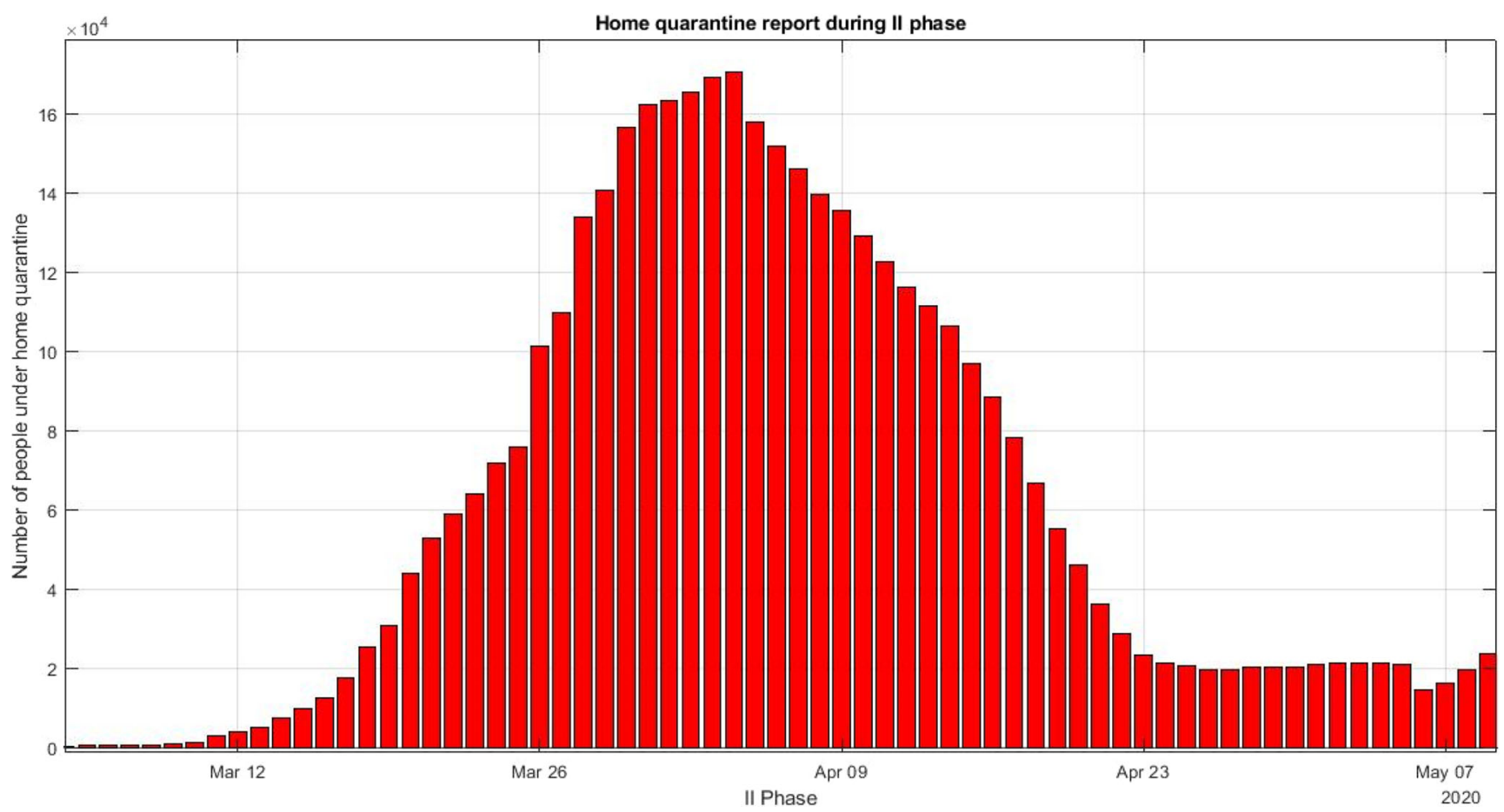

Fig. 10 Home quarantine report during II phase 


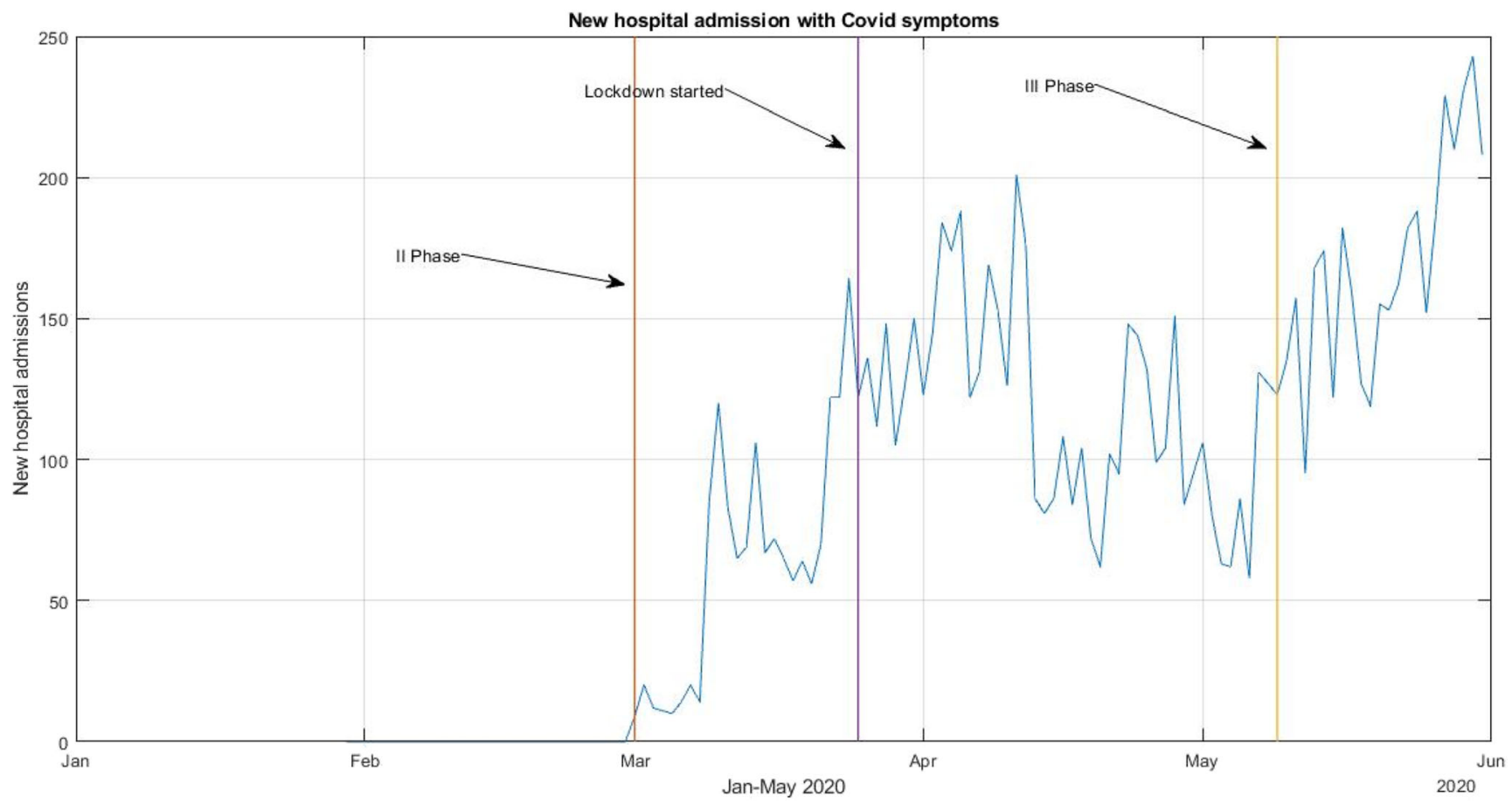

Fig. 11 New hospital admission with Covid-19 symptoms

people under quarantine spiked. As on May 31, 133,413 persons were under home quarantine. Hospital admission details during the three phases are shown in Fig. 11. Two hundred one persons were admitted on April 11 which was the maximum during the second phase. From Fig. 11, it is clear that the lockdown was effective as the number of new admission had a decreasing trend. It reached 58 persons on May 6. After that, in the third phase, the number of hospital admission increased due to the removal of the travel ban.

\section{Community Kitchen and Rehabilitation}

In order to make lockdown period hunger free, steps were taken to ensure the availability of food to everyone in the state.

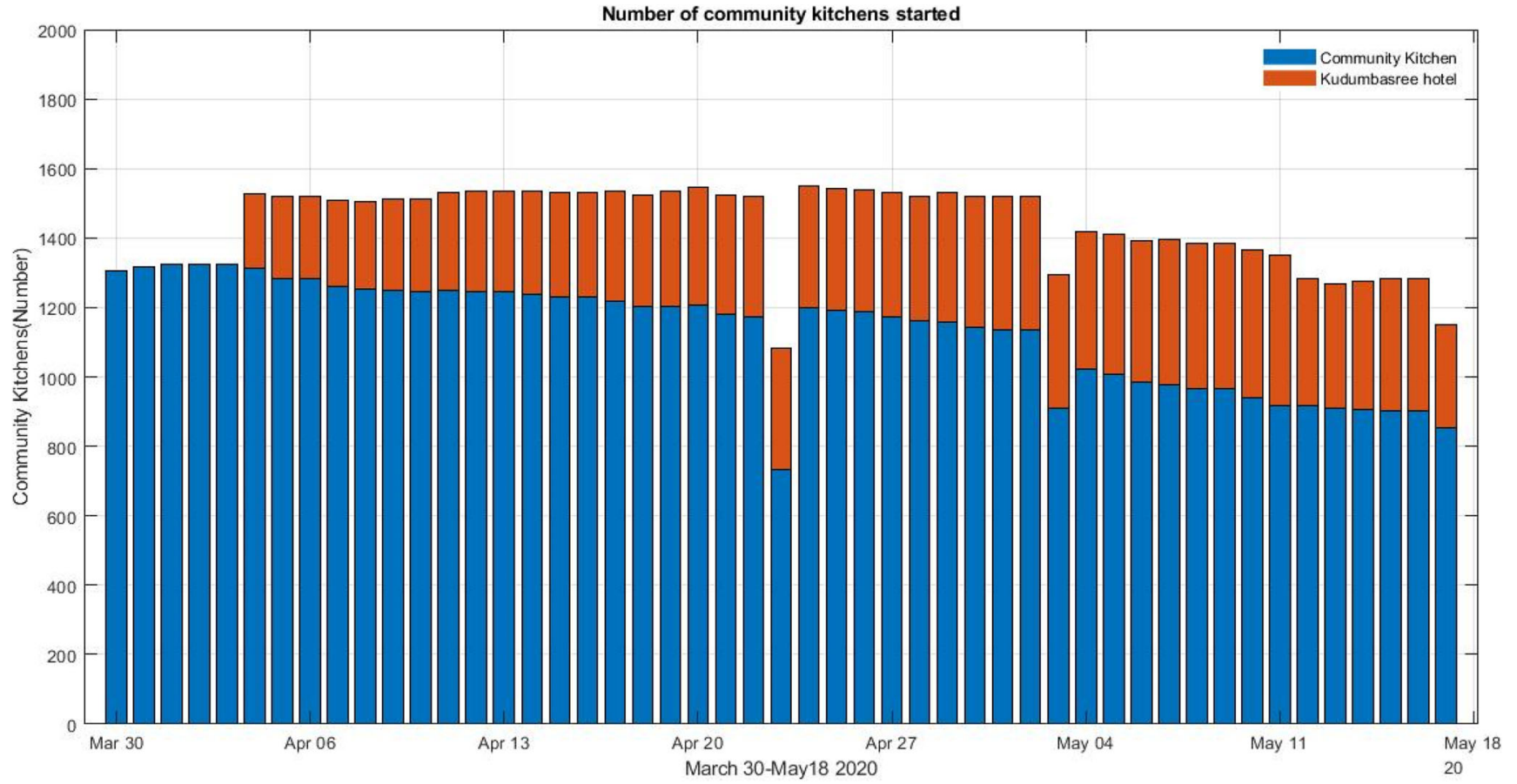

Fig. 12 Number of community kitchen started in Kerala 


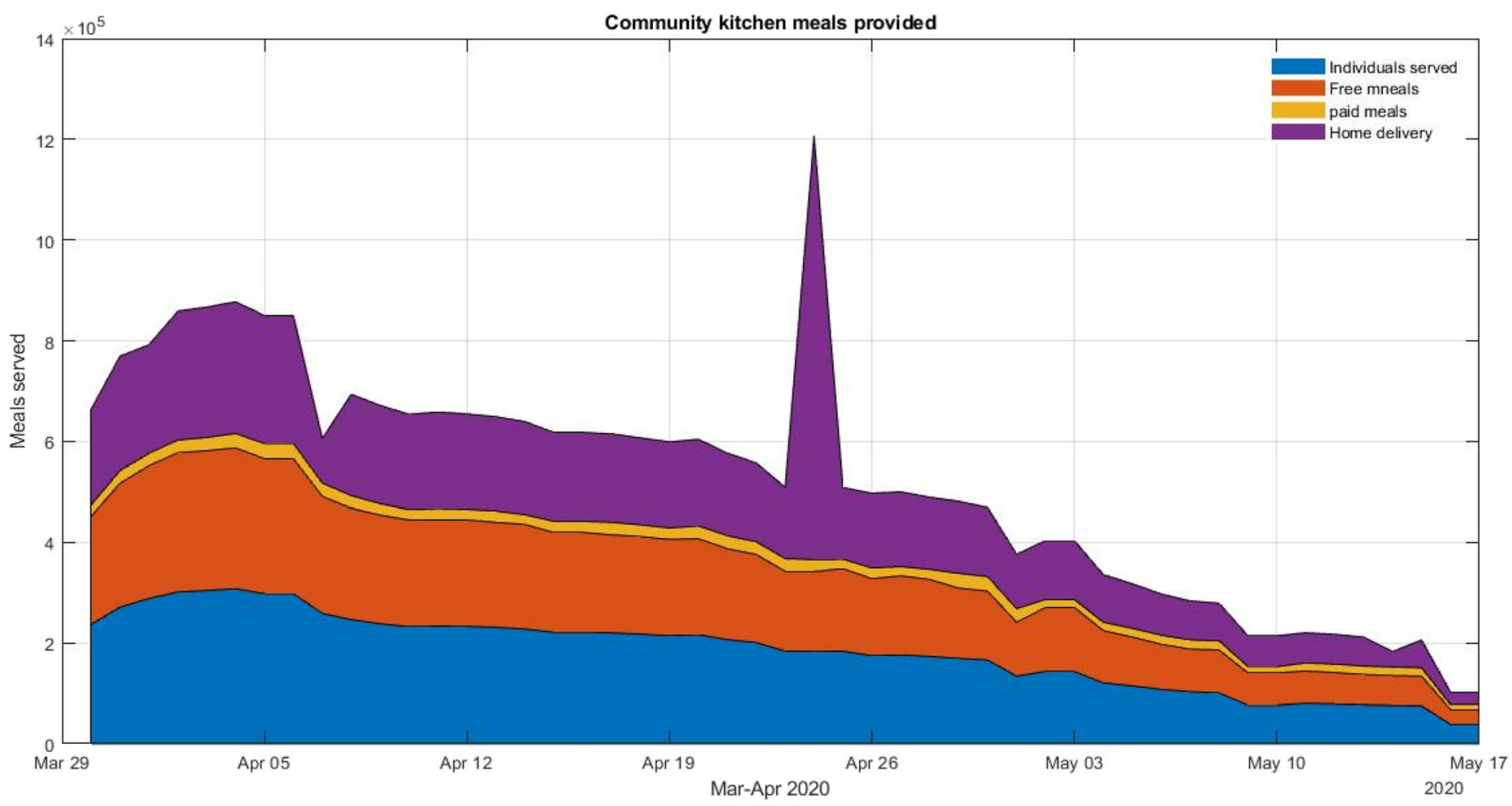

Fig. 13 Meals provided by the community kitchen started in Kerala

For the implementation of this welfare measure, community kitchens were established across the state. Hotels run by the Kudumbasree team were also supported and encouraged across the state. The details are shown in Fig. 12. The public who could pay for food was given paid meals and for the rest, it was accessed free. Community kitchens and hotels worked until May 17 and the details of the number of beneficiaries are shown in Fig. 13. A total of 8,651,627 individuals were served from March 30 to May 17. A total of 7,653,728 individuals were served free food. Rehabilitation for homeless people was also carried out as part of the welfare measures. These measures were taken care of by local self-governing bodies (municipalities, corporations and gramapanchayaths) and coordinated by the state government. The details are shown in Figs. 14, 15, 16 and 17.
Fig. 14 Number of rehabilitation done in Kerala for homeless

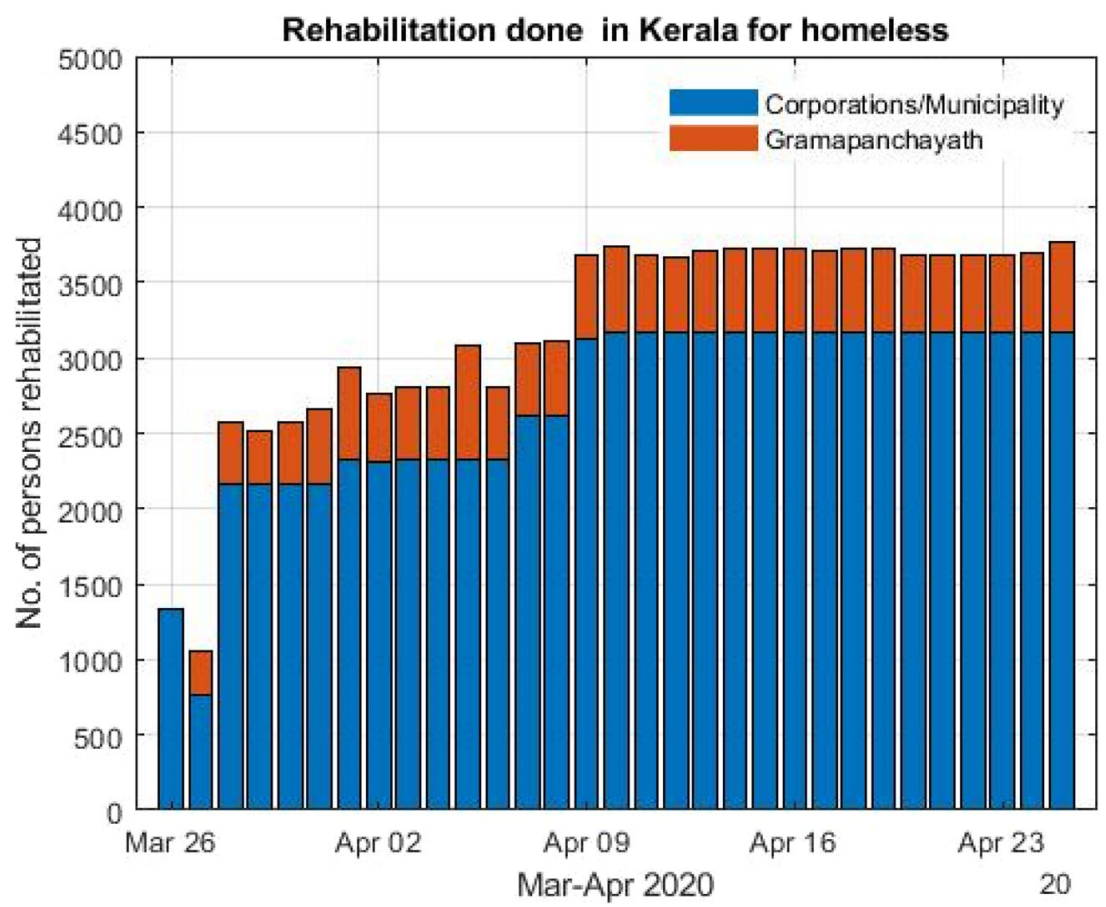




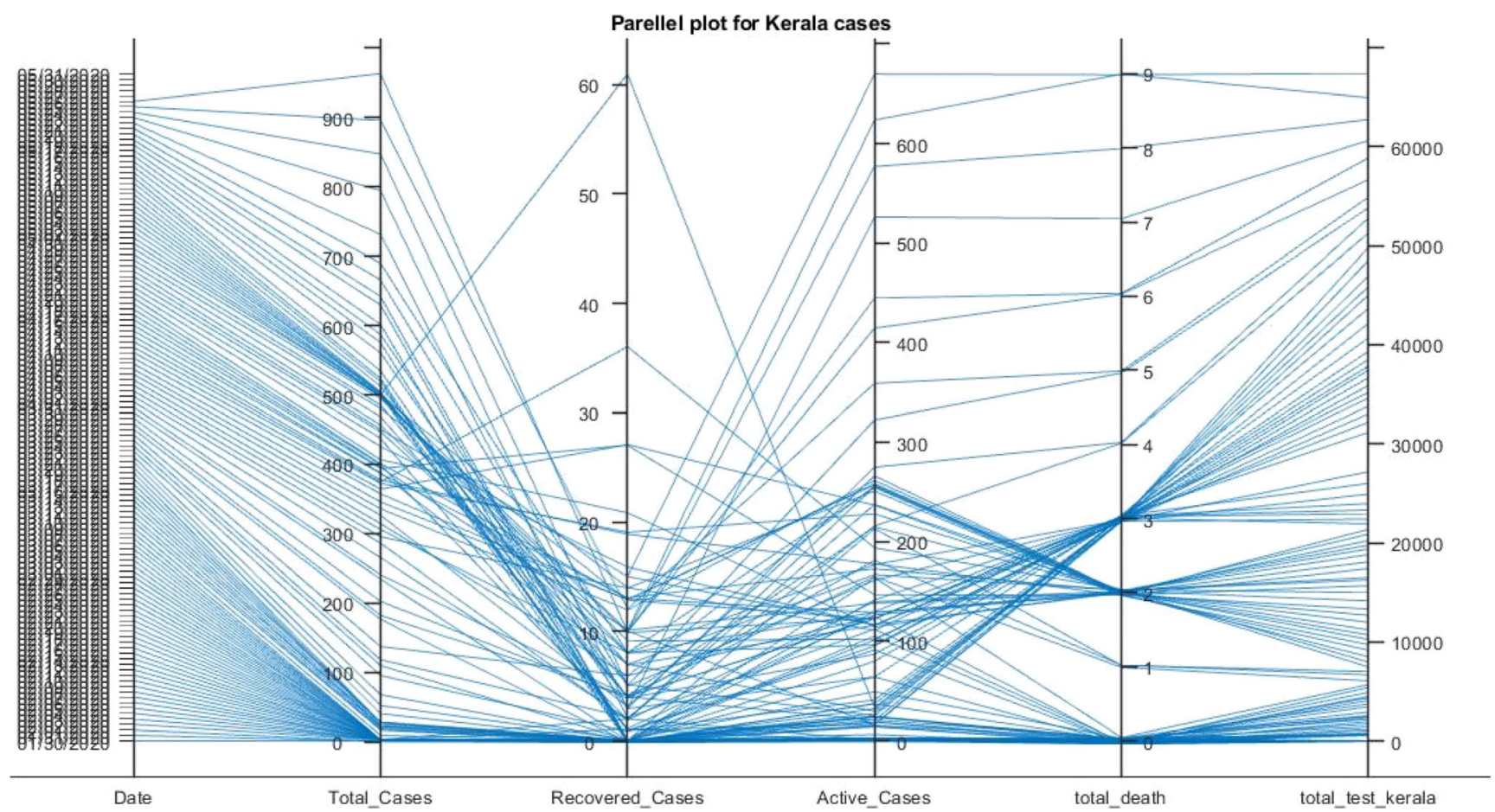

Fig. 15 Parallel plot for Kerala cases

\section{Conclusion}

An exploratory data analysis was conducted on the Covid-19 cases in Kerala. Data were collected from various sources.
Data was cleaned and arranged in order to do the analysis. New cases, death rates, testing, welfare measures, etc. were considered for the analysis. During the first phase, measures taken by the Kerala government could successfully confine

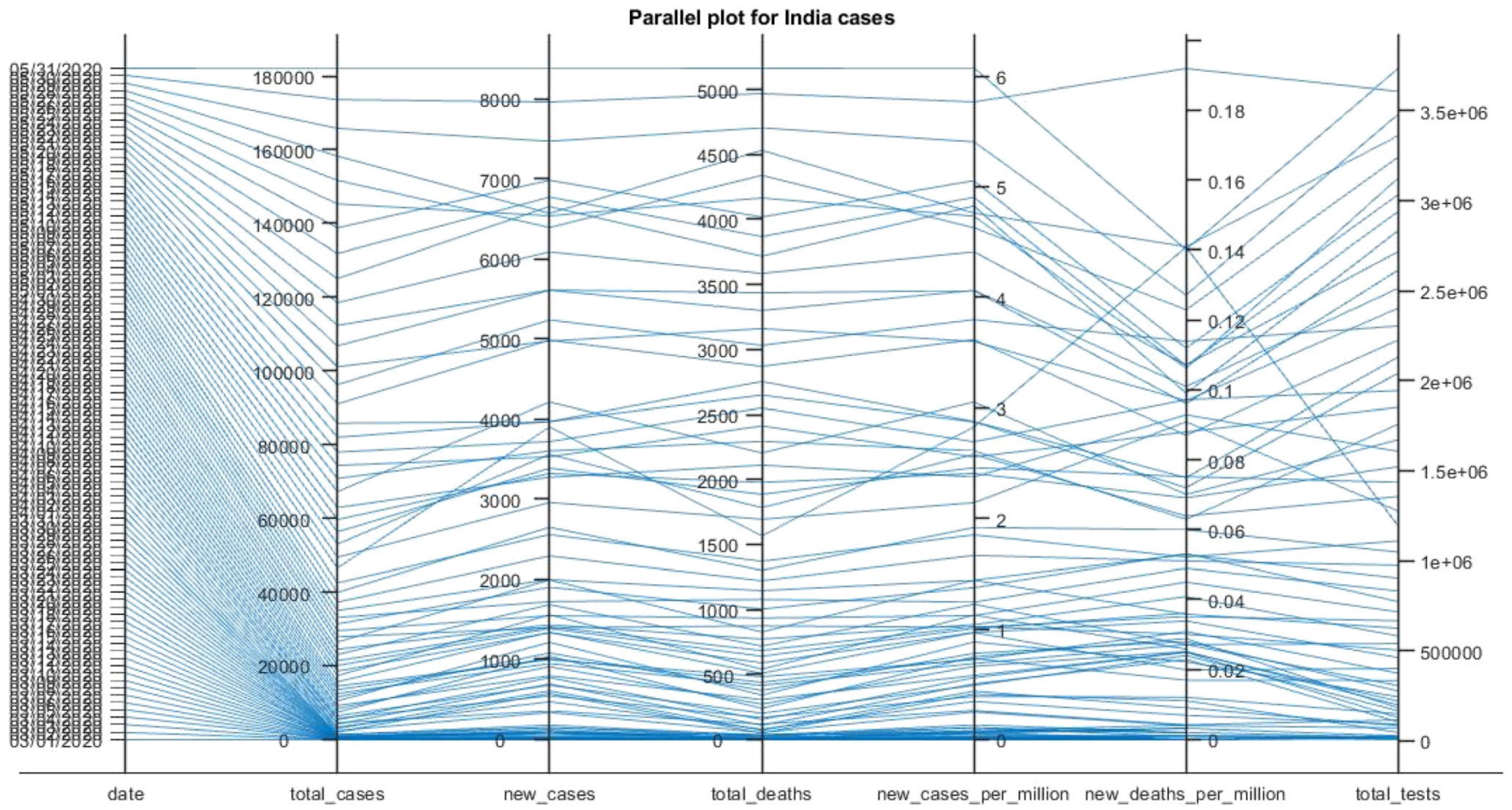

Fig. 16 Parallel plot for cases in India 


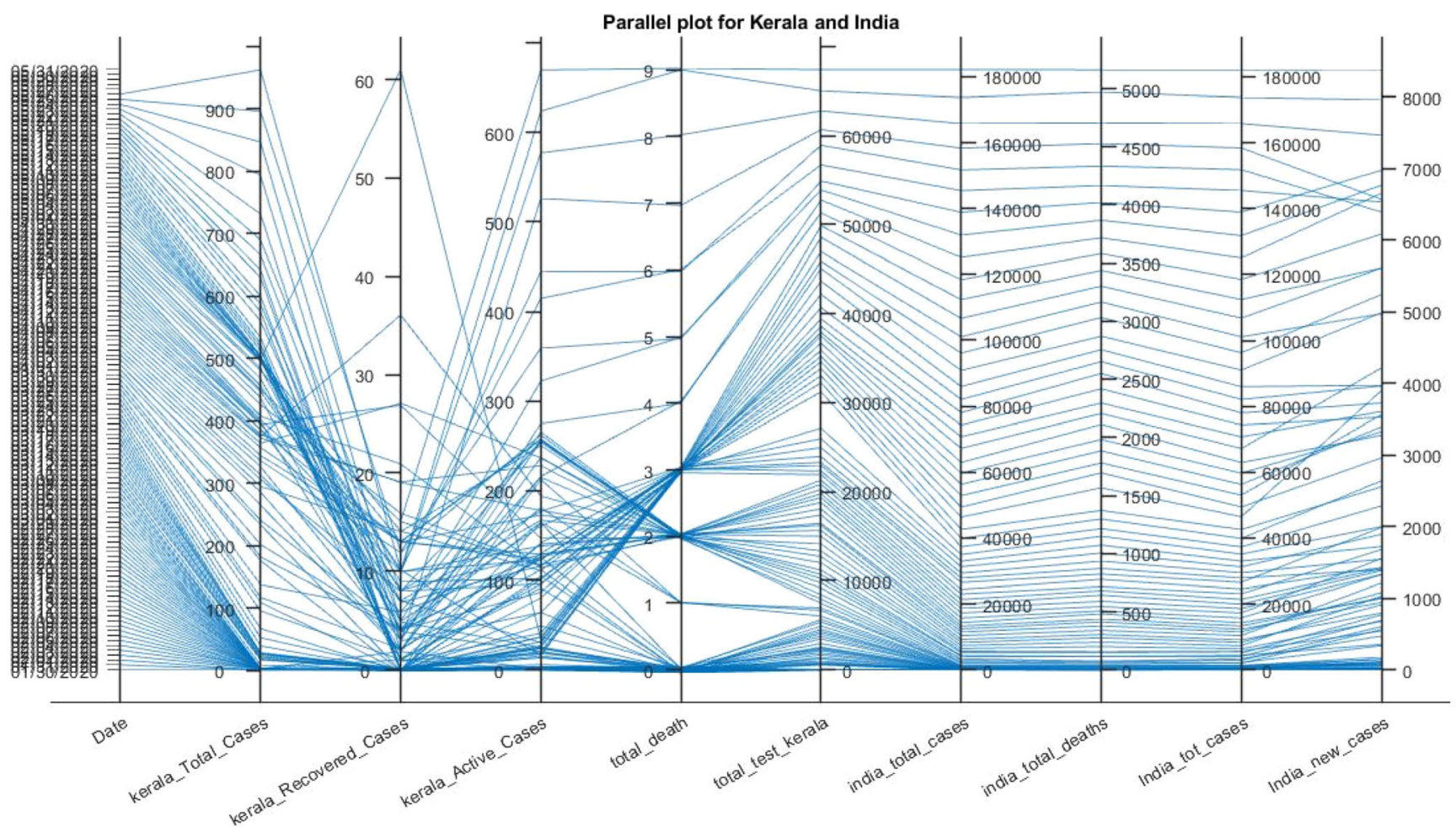

Fig. 17 Parallel plot for cases in Kerala and India combined

the virus to the travellers from China without allowing a fresh case from transmission history. Not a single case was reported in the succeeding month. In the second phase, a handful of tackling measures as well as welfare measures was taken so that the curve of new cases was flattened. In the third phase, as a result of the arrival of interdistrict and international travellers, there is a relative upmounting in the cases. The abstinence of community spread still stands strong. Apart from tackling the Covid-19 virus, Kerala with a series of welfare measures made the life of Kerala citizens comfortable. The model raised by Kerala for fighting against Covid-19 can be considered as a benchmark for how the public health department can be utilised properly.

Acknowledgments The authors would like to thank the World Health Organisation, Kerala State health Department, Our World in Data, Johns Hopkins University, for open sourcing their dataset. The authors would also like to thank the Kerala State Health Department for their timely daily bulletin reports on Covid-19 cases.

\section{Compliance with Ethical Standards}

Conflict of Interest The authors declare that they have no conflict of interests.

Ethical Approval This study does not contain any studies with human participants or animals performed by any of the authors.

Informed Consent This study does not contain any studies with human participants.

\section{References}

1. Fanelli D, Piazza F. Analysis and forecast of COVID-19 spreading in China, Italy and France. Chaos, Solitons Fractals. 2020;134: 109761. https://doi.org/10.1016/j.chaos.2020.109761.

2. Binti Hamzah FA, Lau C, Nazri H, Ligot DV, Lee G, Tan CL, et al. CoronaTracker: Worldwide COVID-19 Outbreak Data Analysis and Prediction. [Preprint]. Bull World Health Organ. 2020. https://doi.org/10.2471/BLT.20.255695.

3. Dey SK, Rahman MM, Siddiqi UR, Howlader A. Analyzing the epidemiological outbreak of COVID-19: a visual exploratory data analysis approach. J Med Virol. 2020;92:632-8. https://doi.org/10. 1002/jmv.25743.

4. https://www.washingtonpost.com/world/aggressive-testingcontact-tracing-cooked-meals-how-the-indian-state-of-keralaflattened-its-coronavirus-curve/2020/04/10/3352e470-783e-11eaa311-adb1344719a9_story.html (Last accessed on June $9^{\text {th }} 2020$ ).

5. https://www.theguardian.com/world/2020/may/14/thecoronavirus-slayer-how-keralas-rock-star-health-minister-helpedsave-it-from-covid-19(Last accessed on June $9^{\text {th }} 2020$ ).

6. https://www.theguardian.com/commentisfree/2020/apr/21/keralaindian-state-flattened-coronavirus-curve (Last accessed on June $9^{\text {th }}$ 2020).

7. https://www.bbc.com/news/world-asia-india-52283748 (Last accessed on June $9^{\text {th }} 2020$ ).

8. https://www.voanews.com/south-central-asia/indias-kerala-stateshows-way-coronavirus-fight (Last accessed on June $\left.9^{\text {th }} 2020\right)$.

9. https://www.indepthnews.net/index.php/the-world/asia-pacific/ 3416-covid-19-the-indian-state-of-kerala-is-a-beacon-to-the-world (Last accessed on June $9^{\text {th }} 2020$ ).

10. https://www.technologyreview.com/2020/04/13/999313/keralafight-covid-19-india-coronavirus/(Last accessed on June $9^{\text {th }} 2020$ ).

11. https://www.prsindia.org/theprsblog/kerala-government\%E2\% 80\%99s-response-covid-19-january-30-2020-april-22-2020(Last accessed on June $9^{\text {th }} 2020$ ). 
12. Arunkumar G, Nipah Investigators People and Health Study Group, et al. Outbreak investigation of Nipah virus disease in Kerala, India, 2018. J Infect Dis. 2019;219(12):1867-78. https://doi.org/10.1093/ infdis/jiy612.

13. https://covid19. who.int/?gclid=Cj0KCQjwiYL3BRD VARIsAF9E4Gc7O-EJ6NDmb_RfKZr_fyhNMJV9-ou1 qzdQoRL7ynldArj-EkaytKoaAvvHEALw_wcB(Last accessed on June $9^{\text {th }} 2020$ ).

14. https://ourworldindata.org/coronavirus (Last accessed on June $9^{\text {th }}$ 2020).

15. https://coronavirus.jhu.edu/(Last accessed on June $\left.9^{\text {th }} 2020\right)$.

16. https://dashboard.kerala.gov.in/index.php(Last accessed on June $9^{\text {th }}$ 2020).

17. Shailaja Teacher," A patient has been tested positive for \#Coronavirus infection and is kept in isolation. Have briefed @ vijayanpinarayi about the situation. We are closely monitoring the situation. There is no need for panic. Our health network is capable of handling any emergency", 30 Jan 2020,04:12 PM.Tweet.

18. http://dhs.kerala.gov.in/wp-content/uploads/2020/03/hae 05022020.pdf(Last accessed on June $\left.9^{\text {th }} 2020\right)$.

19. https://kerala.gov.in/documents/10180/63216aa5-7a97-4782-be56a176e2210a9a(Last accessed on June $9^{\text {th }} 2020$ ).

20. http://dhs.kerala.gov.in/wp-content/uploads/2020/03/reg 12032020.pdf(Last accessed on June $9^{\text {th }} 2020$ ).

21. http://dhs.kerala.gov.in/wp-content/uploads/2020/03/AdisoryAirport-arrangements-and-flow-chart-.pdf(Last accessed on June $\left.9^{\text {th }} 2020\right)$.

22. http://dhs.kerala.gov.in/wp-content/uploads/2020/03/con 19032020.pdf(Last accessed on June $9^{\text {th }} 2020$ ).

23. http://dhs.kerala.gov.in/wp-content/uploads/2020/03/shop 23032020.pdf(Last accessed on June $\left.9^{\text {th }} 2020\right)$.

24. https://kerala.gov.in/documents/10180/0d6aac0c-bc59-4b08-997b$14 \mathrm{cb} 91 \mathrm{f} 446 \mathrm{ec}$ (Last accessed on June $9^{\text {th }} 2020$ ).
25. http://www.lc.kerala.gov.in/images/pdf/gos/20200319_125956. pdf(Last accessed on June $\left.9^{\text {th }} 2020\right)$.

26. http://www.lc.kerala.gov.in/images/pdf/gos/IMG 20200317 0001-1.pdf(Last accessed on June $\left.9^{\text {th }} 2020\right)$.

27. https://kerala.gov.in/documents/10180/9e5888fd-1700-4f59-9810 $59 \mathrm{e} 6 \mathrm{e} 62 \mathrm{~b} 818 \mathrm{f}$ (Last accessed on June $9^{\text {th }} 2020$ ).

28. https://kerala.gov.in/documents/10180/152f3e18-dbfe-4ef5-a11aa332bd4661c2(Last accessed on June $9^{\text {th }} 2020$ ).

29. http://www.lc.kerala.gov.in/images/pdf/enf/covid19circular10 20. $\operatorname{pdf}\left(\right.$ Last accessed on June $\left.9^{\text {th }} 2020\right)$.

30. https://kerala.gov.in/documents/10180/730a7cae-0100-4331-9461b58802 ccce20(Last accessed on June $9^{\text {th }} 2020$ ).

31. https://kerala.gov.in/documents/10180/5c94887f-a383-4239-baf0e8a9bffeac47(Last accessed on June $9^{\text {th }} 2020$ ).

32. https://ksandk.com/wp-content/uploads/2020/03/Government-ofKerala-Passes-Kerala-Epidemic-Diseases-Ordinance.pdf(Last accessed on June $9^{\text {th }} 2020$ ).

33. https://static.mygov.in/rest/s 3 fs-public/mygov 158511610551307401.pdf(Last accessed on June $9^{\text {th }} 2020$ ).

34. https://www.mha.gov.in/sites/default/files/ndma\%20order\% 20copy.pdf(Last accessed on June $\left.9^{\text {th }} 2020\right)$.

35. https://www.mha.gov.in/sites/default/files/MHA\%20order\%20dt\% $2015.04 .2020 \% 2 \mathrm{C} \% 20$ with $\% 20$ Revised $\% 20$ Consolidated $\%$ 20Guidelines_compressed\%20\%283\%29.pdf(Last accessed on June $\left.9^{\text {th }} 2020\right)$.

36. https://kerala.gov.in/documents/10180/3709c74f-3cea-4eaf-86ca$20 \mathrm{~d} 17 \mathrm{f} 8 \mathrm{e} 69 \mathrm{ea}\left(\right.$ Last accessed on June $\left.9^{\text {th }} 2020\right)$.

37. https://go.lsgkerala.gov.in/files/go20200404_25961.pdf(Last accessed on June $9^{\text {th }} 2020$ ).

Publisher's Note Springer Nature remains neutral with regard to jurisdictional claims in published maps and institutional affiliations. 